\title{
The Development of Legha Sumenep Madura Bride Wedding Dress
}

\author{
Iut Nur Aini ${ }^{1 *}$ Amat Nyoto ${ }^{2}$ Agus Hery Supadmi Irianti ${ }^{3}$ \\ ${ }^{1}$ Vocational Education Study Program Postgraduate Universitas Negeri Malang \\ ${ }^{2}$ Mechanical Engineering Department Universitas Negeri Malang ; \\ ${ }^{3}$ Department of Industrial Universitas Negeri Malang Malang, Indonesia; \\ *Corresponding author, E-mail: nurainiiut@gmail.com
}

\begin{abstract}
The aims of this study is to develop Legha Sumenep Madura bridal wedding dress. This research uses research and development methods. The method used is the ADDIE model development method. The results of this study are Based on the ADDIE development analysis, there are five parts of Legha wedding dress which are developed; kemben that becomes red after being developed, long cloth that becomes red after being developed, rapek becomes red after being developed, odhed that the belt and the odhed are not separated, but become one after being developed, and After being developed, temang is being one with odhed. The conclusion of this study is development of the Legha Sumenep Madura bridal dress in this study includes five parts namely kemben, rapek, long cloth, odhet and, timang belt. In developing the Legha wedding dress, it refers to the design development criteria, namely Utility, Comfort, Flexibility, Safety, and Beauty.
\end{abstract}

Keywords: development, Legha Sumenep Madura Bride wedding dress, ADDIE

\section{INTRODUCTION}

Legha bride wedding dress comes from Sumenep Madura. Legha's fashion is the richest of her trinkets. This outfit is in great demand by both Sumenep people, and people outside Sumenep.

This bridal fashion has a philosophy related to the history of the palace. The fashion philosophy lies in the color, shape, and name of the clothing itself.

The interest of people using these clothes at weddings is very high, for example in Surabaya the clothing is often used. Even though the Sumenep people have moved places, they still wear the Legha bridal attire when the wedding takes place.

Legha wedding dress has a deep philosophy, which has always been preserved. The Legha bride still maintains fashion both in terms of shape and color that has philosophical meaning.

Legha which has its own standard as has become the official custom of Sumenep Regency residents. However, along with the times and the many people of Sumenep who have moved to the cities, there have been several changes to the Legha business in marriage. There are modifications related to Legha clothing both in terms of shape and color.

Thus, it is necessary to develop the Legha bridal women's clothing, in order to give a modern and practical impression without leaving the philosophy. The reason researchers develop is because researchers want to preserve culture as the wealth of the Indonesian people, especially with the bride bride Legha Sumenep Madura.

\section{THE AIM OF THIS STUDY}

The aim of this study is to develop Legha Sumenep Madura bridal wedding dress.

To be able to develop Legha wedding dress, the researcher needs to consider the philosophies that are in the Legha bride. These are used as conditions for developing a Legha wedding dress.

\section{RESEARCH METHODOLOGY}

This research uses research and development methods. The method used is the ADDIE model development method. ADDIE development model is a product development design model based on an effective and efficient system discussion as well as an interactive process that contains the results of the evaluation of each phase that can result in product development to the next phase. The final product of the phase is the initial product for the next phase.

This model consists of 5 main phases or phases 1) Analysis, 2) Design, 3) Development, 4) Implement, 5) Evaluation 


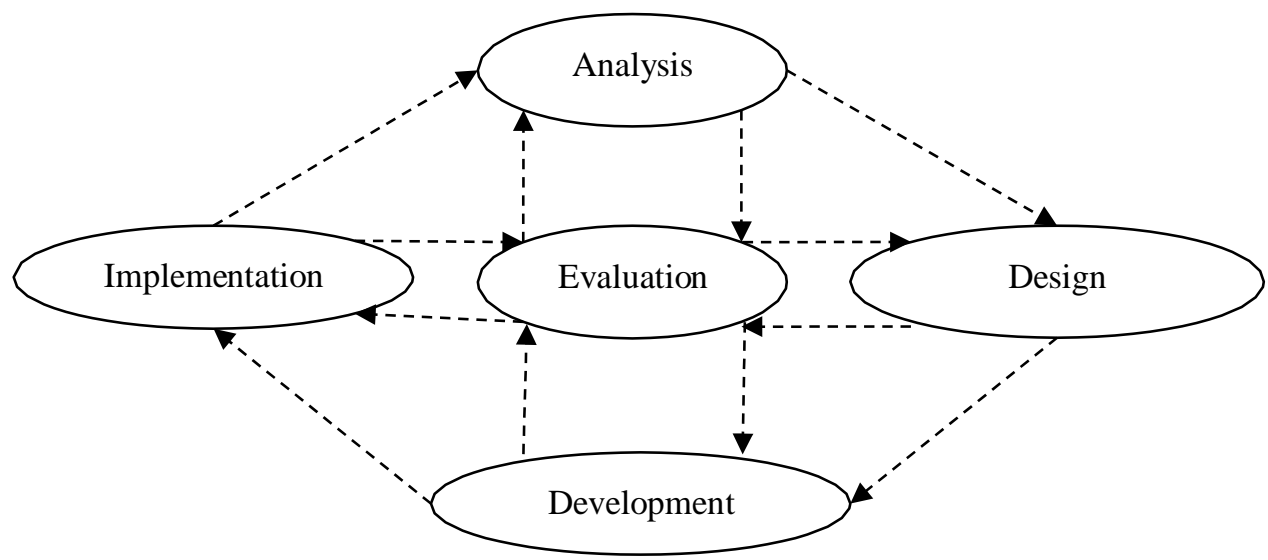

Figure Stages of the ADDIE development model The stages of the ADDIE

Model are as follows:

a. Analysis phase: a process of defining what the researcher will develop. In order to know or determine what should be developed, then do a) needs assessment, b) identify problems, dan c) do a task analysis. The output will be in the form of product characteristics, product gap identification, identification of needs and detailed product analysis based on needs. teps that must be taken at this stage are to formulate development goals. Then determine the development strategy to achieve goals. In this case there are many choices of combinations of methods and media that can be selected and determined the most relevant. The output will be in the form of a modern bridal makeup style of the Legha Madura bride.

b. Development stage: development is the process of realizing the blueprint or design becomes reality. An important step in the development phase is a trial before it is implemented. This trial phase is indeed part of one of ADDIE's steps, which is evaluation. The results are used to improve the product being developed. The output will be in the form of a validated product draft and a revised draft of the validated product and followed by a trial.

c. Implementation stage: concrete steps to implement the product development that is being made. That is, at this stage everything that has been developed is set in such a way as to suit its role or function in order to be implemented. Output in the form of trial results.

d. Evaluation stage: evaluation is the process of seeing whether the product developed is in line with initial expectations or not. Actually the evaluation phase can occur at any of the four stages above. Evaluations that occur at each of the four stages above are called formative evaluations, because the purpose is for revision needs. For example, at the design stage, we might need one form of evaluation formative for example expert review to provide input on the product design being made. At the development stage, it might be necessary to test the products we develop or might need a small group evaluation. The output that will be generated is in the form of a revision of the trial validation product which is the final product.

\section{DEVELOPMENT RESULTS}

The results of the development of the Legha wedding dress have been validated by experts consisting of lecturers, Legha bridal make-up practitioners, and the Legha bridal wear community. Based on the questionnaire results, it can be seen that of the 30 people who are familiar with the Legha bridal dress, the majority or $70 \%$ expressed their liking to the results of developing this Legha bridal dress.

Based on the ADDIE development analysis, there are six parts of Legha wedding dress which are developed; kemben, long cloth, rapek, odhed, temang belt and tail. a. Kemben

The colors of kemben in Legha wedding dress before being developed are green and black. The materials of kemben are satin cloth and bone. Outside the Kemben tulang (bride) must be given one more cloth. After being developed, the color becomes red. The materials of this cloth are velvet, batik madura and beads. Below are the before and after development pictures: 


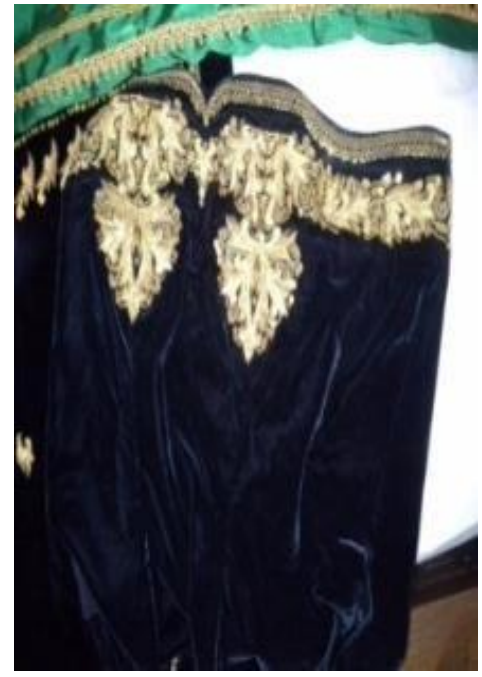

Before

b. Kain panjang

The colors of long cloth of Legha wedding dress are black and gold. The materials of this cloth are velvet and beads. After being developed, the colors of long cloth

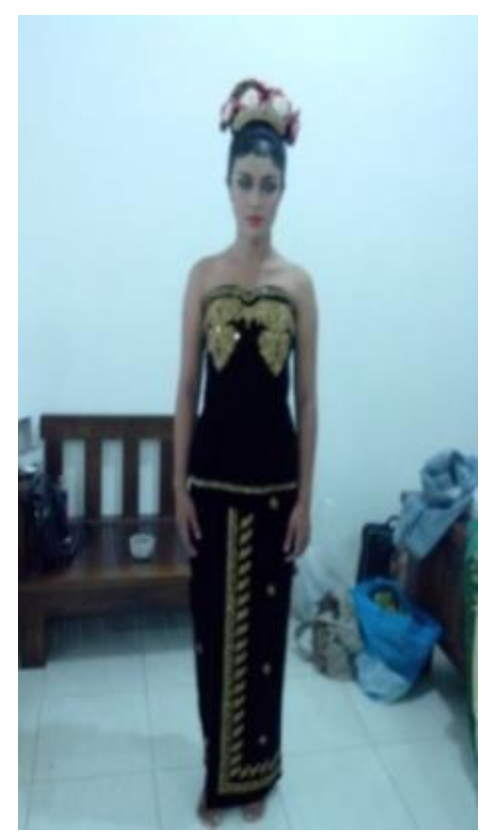

before

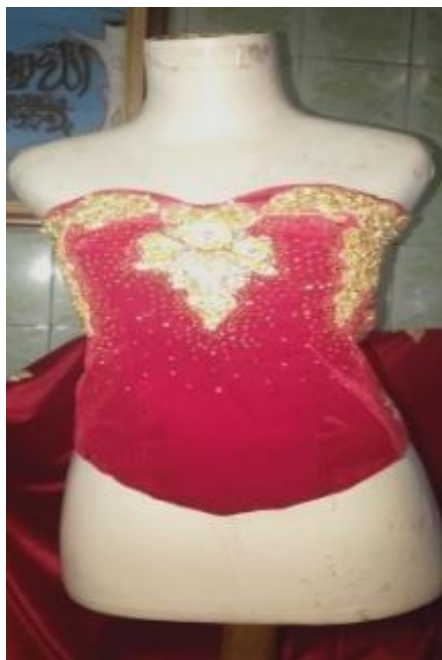

after

becomes red. The materials of this cloth are velvet, batik madura and beads. Below are the before and after development picture:

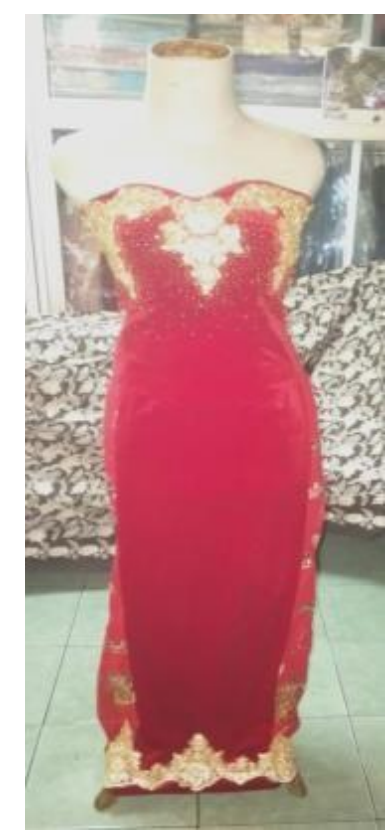

after 
into two has green color outside and has yellow color inside. Pare fruit has many benefits to human body, so the philosophy of the color of rapek is having many benefits.

The rapek form is rectangle. The materials of rapek are saten cloth and burci. This development used red yellow. The materials of this cloth are masmara and roberto. Below are the before and after being developed pictures: means Dutchman that has reddish skin racked the Indonesian that has yellow complexion skin. Meanwhile green is based on Pare Anom, Pare fruit that if it is split

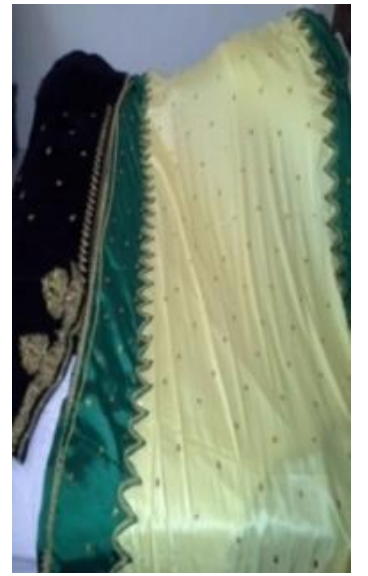

Before
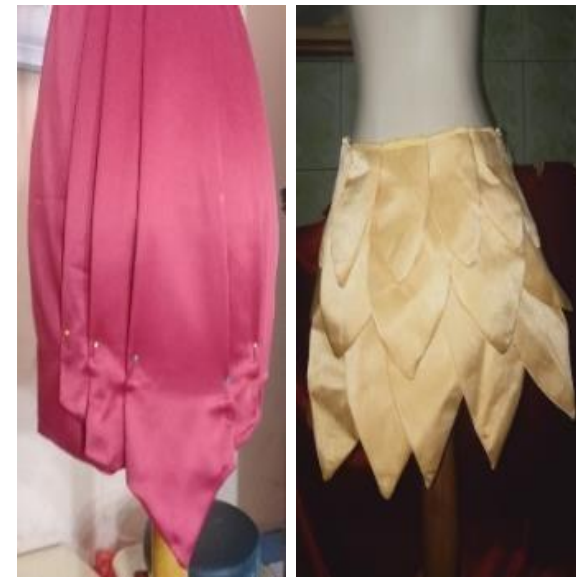

After

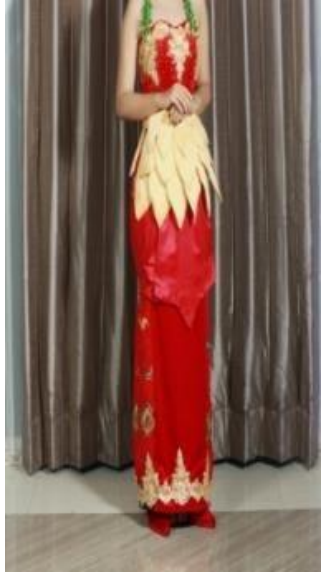

(n)

\section{d. Odhed}

The form of Odhed is a piece of velvet cloth from hip to knee that the belt and the odhed are separated. After being developed, the belt and the odhed are not separated, but become one. Below are before and after being developed pictures:
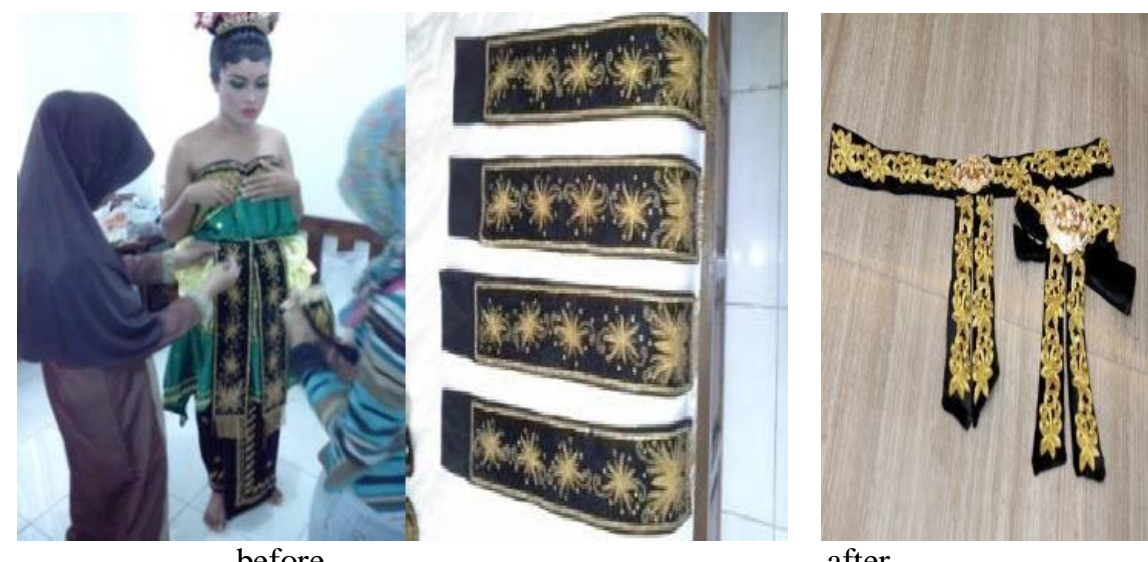

after

\section{e. Temang Belt}

The belt has philosophy; so that people who use their body to work hard, meanwhile temang has philosophy; symbol that people must understand the knowledge they learn clearly, so that the people do not have anxiety. After being developed, temang is being one with odhed. Below are the before and after being developed pictures: 


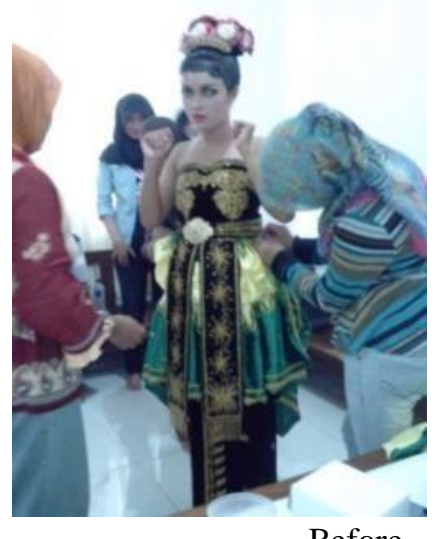

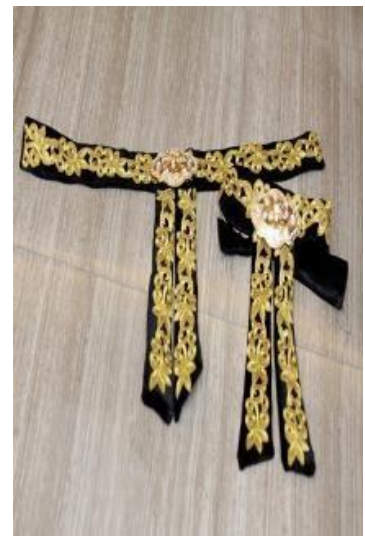

After

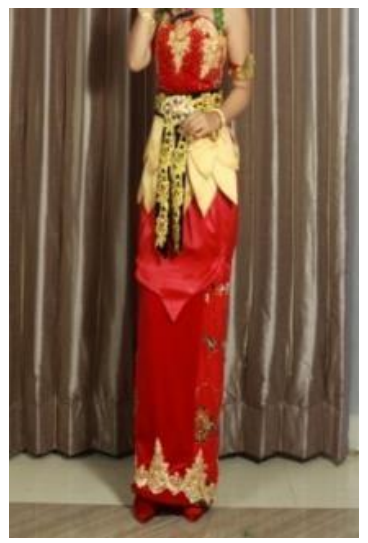

f. Tail

Then in this time development, a bridal fashion Legha use long cloth more for tail. And fabric used is velvet and beads.

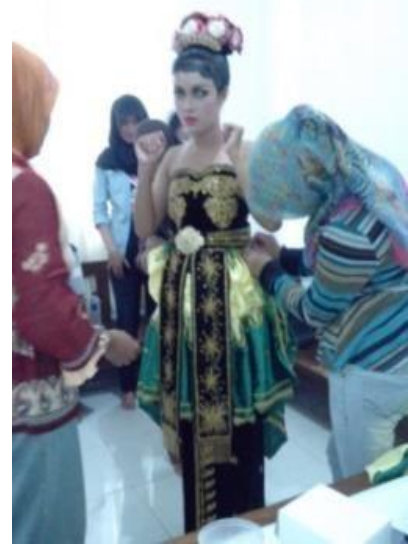

Before
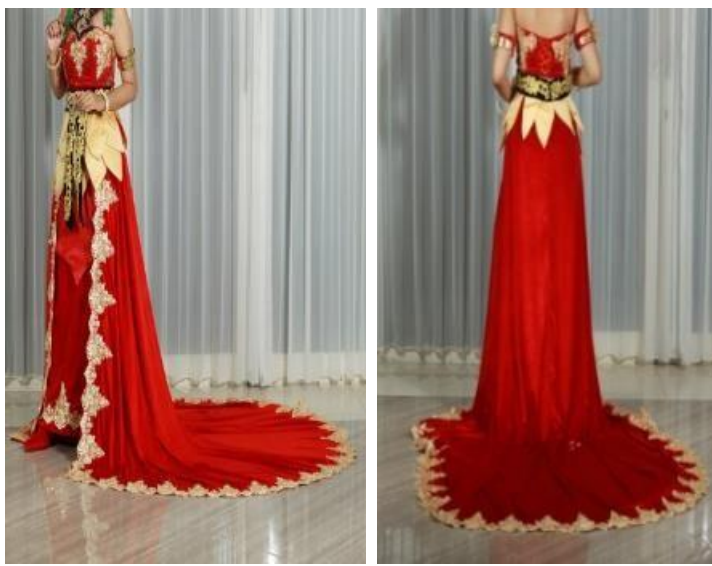

After
In developing the design of the Legha bridal dress in this study, the researcher considered the design criteria, those are:

\section{a. Utility}

The design of the Legha wedding dress emphasizes practical value, which can be used more easily. When compared to the clothing before it was developed, the Legha bridal dress after it was developed was more practical and easier to use. Things that can be called practical include the ease of wearing a dress (Arifah, 2003: 90).

b. Comfortable

The design of Legha bridal fashion development is more fun and gives comfort to the wearer. Comfort in this case better meets health needs, which is functioning to defend themselves from various natural challenges, for example from heat and rain. One that can be used as a tool to protect the body, that is, if the body, model, color and in accordance with the climate and weather conditions in the environment where the clothes are used. The faster a process and the absence of complexity, it can be stated that the process has fulfilled the convenience aspect. (Arifah, 2003: 90).

\section{c. Flexibility}

Legha wedding dress designs must have harmony between the shape and shape of the clothing.

d. Safety

Legha wedding dress designs are safer and more comfortable to wear because they use better material than the clothes before they were developed.

e. Aestetic

The design of the Legha wedding dress in this development pays attention to the element of beauty and beauty.

In addition, in developing the design of the Legha wedding dress, attention is paid to the accent element to create a unified impression. Accent serves to cover up the lack of accentuating the beauty of body shape with distraction techniques (Soekarno: 2004: 12).

The proportion in developing a Leghanting dress is also considered. Proportion is the ratio between one part with another part combined (Jennings, 2011: 35). 


\section{CONCLUSION AND SUGGESTION}

Based on the results and discussion above, it can be concluded that the development of the Legha Sumenep Madura bridal dress in this study includes six parts namely kemben, rapek, long cloth, odhet, timang belt and tail. In developing the Legha wedding dress, it refers to the design development criteria, namely Utility, Comfort, Flexibility, Safety, and Beauty.

This development research is still limited to the Legha wedding dress, it is hoped that further research can develop in terms of cosmetology and accessories.

\section{REFERENCES}

[1] Arifah A.Riyanto, 2003. Desain Busana, Bandung:Yapendo

[2] Harrington J.M, Gill, 2005. Buku saku Kesehatan Kerja. Jakarta: Buku Kedokteran EGC

[3] Ibrahim, Reyzal. 2011. Model. Pengembangan. ADDIE diakses melalui http://jurnalpdf.info/pdf/model-pengembanganaddie.html diakses tanggal 10 Maret Maret 2018.

[4] Jennings, Tracy.2011. Creativity in Fashion Design. USA: Conde Nast Publication

[5] Sukarno, Lanawati Basuki. 2004. Panduan Membuat Desain Ilustrasi Busana. Yogyakarta : Kawan Pustaka. 